\title{
An Assessment of the Level of Compliance of GSM Mast Location to Environmental Standard Regulations
}

\author{
Oruonye $\mathrm{ED}^{1 *}$, Felix Jutum ${ }^{1}$, and Ahmed YM
}

\author{
${ }^{1}$ Department of Geography, Taraba State University, P.M.B. 1167, Jalingo, Taraba State \\ DOI: $10.36347 /$ sajb.2021.v09i04.001 \\ | Received: 14.03.2021 | Accepted: 21.04.2021 | Published: 27.04.2021
}

*Corresponding author: Oruonye ED

Abstract

Original Research Article

The increase proliferation of GSM masts across the country has generated a lot of concern among the publics and brought to the fore, the need for assessment of the level of compliance to environmental standard regulations. The study therefore examined the level of compliance of GSM mast location to environmental standard regulations in Jalingo town, Nigeria. The specific objectives of the study include mapping out the location of GSM mast and assessing the level of compliance to environmental standard regulations in the study area. Geo-database was created using ArcGIS 10.1 software to show the spatial location and distribution of base stations on the map across the study area. The buffering of 5 and 10 meters was created around GSM Base Stations using buffer Tool of the Geo-processing Tool Box in ArcGIS. A total of $59 \mathrm{GSM}$ masts were identified across the town. The result of the findings shows that $89.8 \%$ of the masts violated the regulatory setback and only $10.2 \%$ masts adhered to the regulatory standard. The environmental effects of GSM masts locations such as oil spillage into wells, mast falling, building cracks/collapse, were observed to be more severe in areas closer to the mast and decreases as the distance increases away from the masts, due to clustering of houses around the masts, which indicates a violation of the $5 \mathrm{~m}$ and $10 \mathrm{~m} \mathrm{NCC}$ / NESREA regulations. The study recommends that the minimum regulatory setback distance policy be harmonized by both the NCC and NESREA since noise hazards are still reported at some distance away. Also, the regulatory agencies should intensify strict enforcement of proscribed laws and regulations. The study further recommends that regulatory agencies (NCC/NESREA) should create public awareness and sensitization campaign on the risks involved with residing in close proximity to telecommunication masts.

Keywords: BTS, Environmental compliance, Environmental regulations, Environmental standard and GSM Mast.

Copyright ( 12021 The Author(s): This is an open-access article distributed under the terms of the Creative Commons Attribution 4.0 International License (CC BY-NC 4.0) which permits unrestricted use, distribution, and reproduction in any medium for non-commercial use provided the original author and source are credited.

\section{INTRODUCTION}

GSM was introduced in Nigeria on May, 2001, following the liberalization of the telecommunication sector of the economy [1]. Since then, the domination of the Nigerian telecom industry by GSM accounts for about $98 \%$ share of the market [2]. Four GSM operators: MTN, AIRTEL, ETISALAT, and GLOBACOM control the industry in Nigeria [3]. As at May 2014, the four major GSM operators had collectively grown the telecom subscriber base from 260,416 in 2001, to over 131 million active lines [1]. Following this rapid growth in subscriber base, the number of deployed transceiver stations (BTSs) grew from less than 80 in 2001 to about 44,000 in May 2014 [2]. For GSM service providers, the primary consideration when locating BTS sites is finding sites that provide the best possible coverage in the area without causing interference with other "cells" and one that causes the least amount of environmental impact on the surrounding area [4].
The growing concerns over the proliferation of telecom BTSs and masts is due to the perceived deleterious effects of radio frequency radiation produced by these devices on human health [5], and danger associated with the fall zone of the masts [6]. There is obviously conflicting information from the various scientific sources and environmental groups with respect to health hazards associated with GSM telephony [7].

Cherry [8] stated that cell sites are risk factors for cancer, specifically brain tumours and leukaemia; heart attack and heart disease, particularly arrhythmia; neurological effects including sleep disturbance, learning difficulties, depression and suicide; reproductive effects, especially miscarriage and congenital malformation; viral and infectious diseases because of reduced immune system competency associated with reduced melatonin and altered calcium ion homeostasis. Lai [9] in considering the health effect of radiation from BTSs, stated that people who live, attend school, or work close to BTSs are constantly 
being exposed to the radiation for months or years. Lai [9] was of the opinion that, though the level may be low, it would matter if the effects of radiofrequency radiation turn out to be cumulative. No matter how long, the cumulative effects of radiation from BTS would still manifest [9].

According to medical reports, some ailments are caused by radiation or emission of electromagnetic impulses from a telecom mast erected close to residential premises [10-12]. These masts transmit harmful gases that are deleterious to the immune system and human neurological functions. Frequent and close contacts with the radioactive substances could hamper memory and sleep patterns, cause brain tumours, cancers and Alzheimer's disease (loss of memory and ability to speak clearly in older people). The radiation impacts on fertility and metabolism can cause depression and fatigue [12].

The World Health Organization [13] warns that a telecommunication (telecom) mast should be located at least 10-metre radius away from a residential quarter. The Nigerian Communications Commission (NCC) is the sector-specific regulator in the Nigerian Telecommunications Industry while the National Environmental Standards and Regulations Enforcement Agency (NESREA) is charged with the responsibility of protecting and developing the environment.

Given the potential environmental risks and health impacts of BTSs and Masts, the National Communications Commission (NCC) and the National Environmental Standards and Regulations Enforcement Agency (NESREA) established both technical specifications and environmental guidelines for telecommunications and broadcasting facilities in Nigeria in 2009 and 2011 respectively. The environmental guidelines provided for the space requirements, height, set-back, residential areas, screening, tower-to-tower spacing, nearness to power lines, and co-location requirements. There have been growing concerns that the GSM operators do not comply with these guidelines in the construction of BTSs and masts after they have duly secured approvals from the relevant authorities [14]. Akindele and Adeniji [14] discovered that masts are often installed closer to homes, signifying non-adherence to the minimum setback standard which is $10 \mathrm{~m}$ as required by NESREA regulations. In recent years both the NCC and NESREA have taken court actions against some GSM operators, as well as threatened to shut down some BTSs. Bond, Mun, Sakornvanask and MacMahon [15] stated that despite the several perceived health-related challenges attributed to electromagnetic emissions from BTS, it appears people do not see the danger in residing or doing business in close proximity to BTS.

Many Nigerian landlords let out their pieces of land for erection of telecom masts near residential and educational facilities without considering the health hazards that may arise there-from. On their part, telecom firms intentionally capitalize on the people's ignorance to erect telecom masts, putting the people in grave danger. This scenario could also be attributed to poverty or greed on the part of the landowners or property owners [12]. The high rate of poverty in the country makes people vulnerable.

Many studies have been carried out in different parts of the country to assess the location and distribution of GSM mast and level of compliance to environmental standard regulation, but not much has been done in Jalingo town. This study thus examines the level of compliance of GSM masts location to environmental standard regulations in Jalingo, Taraba State, Nigeria. The specific objectives include identifying the location of GSM masts and the level of compliance to environmental standard regulations in Jalingo town.

\section{Conceptual Clarifications}

\section{Compliance}

Environmental Compliance means conforming to environmental laws, regulations, standards and other requirements such as site permits to operate. In recent years, environmental concerns have led to a significant increase in the number and scope of compliance imperatives across all global regulatory environments. Being closely related, environmental concerns and compliance activities are increasingly being aligned with corporate performance goals and being integrated to some extent to avoid conflicts, wasteful overlaps, and gaps [16].

According to Silberman [17], the implementation of environmental policies requires a strict and concerted action guided by the principle "trust and check" to ensure effective and efficient protection of human health and the environment. To this end, compliance assurance systems, including elements of prevention and cure, are established to influence positively the behaviour of the regulated community and make its members comply with environmental requirements. Voluntary compliance and reversal of an offence can be considered the main goal of inspection and enforcement. Punishment of the offender should be a secondary purpose. An important goal of compliance assurance is to provide a basis for public confidence about e.g. the safety of hazardous installations and the preservation of natural values. Furthermore, in the framework of environmental policy implementation, compliance assurance systems support the fulfilment of objectives laid down in legal acts and planning documents by enforcing the rule of law and also by providing proper feedback that helps improve environmental policy and law [17].

The principle of deterrence underlies the compliance assurance systems. Inspections and other 
forms of compliance monitoring and enforcement are undertaken not only to identify specific violators and return them to compliance, but also to deter the violators and all other similarly situated regulated entities from non-compliance. Underlying this paradigm is the assumption that most regulatees will comply with the law when costs of non-compliance exceed the benefits. By recuperating the unlawful benefits gained by the violator, compliance assurance systems help maintain the level playing field and ensure that no company obtains a competitive advantage from its non-compliance [17].

This enlarged understanding of the aim of compliance assurance is closely linked to the diversity of solutions that are applied to achieve environmental policy goals [18], i.e.:

i. Direct regulation, by setting legal requirements or by issuing licenses, followed by inspection and enforcement;

ii. Indirect regulation, by promoting behaviour through other means than inspection and enforcement, e.g. by using information-based instruments, providing economic incentives and education, etc.

Self-regulation, by adjustment of behaviour by the regulated community itself, because they believe it is just to do so.

\section{NCC and NESREA Standards for Base Transceiver Stations}

The maximum height that may be approved for telecommunication tower in Nigeria is $150 \mathrm{~m}$. A tower more than $50 \mathrm{~m}$ in height may be approved by Nigeria Communication Commission (NCC) if the commission is satisfied that the increase height of tower [19];

i. Will not be detrimental to the public health, safety or general welfare.

ii. Will not have a substantial negative effect upon neighborhood.

iii. Is in conformity with the intent and purpose of the planning of the area and the general plan of the community.

iv. Will not impair the obligation to comply with any other applicable laws or regulations.

\section{Technical Specifications for the Installation of Telecommunications Masts and Towers}

By the power conferred upon it under the Act, the NCC published Guidelines on Technical Specifications for the Installation of Masts and Towers in 2009. The guidelines provide standards to be adhered to by telecommunications services providers/operators, designers, fabricators and installers of telecommunications towers towards ensuring environmental safety and sound engineering practices. The guidelines take cognizance of types and constituents of tower structures and also provide a comprehensive data on wind speed in Nigeria which may be used as reference materials for engineers in the design of masts and towers. In the guidelines, concerns about public safety and safety of personnel and equipment are addressed and accordingly the responsibilities of owners, designers and fabricators of telecommunications masts and towers relating thereto are set out [19].

\section{Siting of Towers and Masts}

The sitting of telecommunication masts and towers must take cognizance of the provisions of the Nigerian Communications Act and be guided by the provisions of the Guidelines on Collocation and Infrastructure Sharing issued by the Commission, in such a way as to minimize the number, protect and promote public safety, and mitigates adverse visual impacts on the community. All masts and towers sited within residential areas must conform to the stipulated set back guidelines to mitigate the effect of heat, smoke and noise pollution arising from generating sets. Thus, the general rule is that telecommunications towers above 25 metres in height would not be permitted within residential areas. However, the Commission may permit towers above 25 metres height and in such a case, the towers must be placed at a minimum of 5 metres distance to the nearest demised property, excluding the fence. What is important here is that prior permission of the NCC must be obtained. The commission reserves the power to remove any tower or mast sited in contravention of the guidelines on sitting of towers and masts and the owner would bear the cost of such removal. All towers must be located within the buildable area of the property and not within the front, rear or side building setbacks. All towers in excess of 150 metres in height must be set back by a minimum of 50 metres from the right of way of all controlled access designed as freeways in order to provide unobstructed flight paths for helicopter. In respect of demised properties, the distance for setback is 5 metres excluding the fence or the distance specified as a potential hazard area by the designer of the structure [19].

\section{Structural Certification}

Before the installation of a tower, mast or antenna support structure on any building or roof, the commission must be provided with a structural engineer's certification that the structure will support and not be adversely affected by the proposed masts, tower, antenna and associated equipment [19].

Ogbonna, Okoye and Eleazu [1] in a study of compliance of GSM service providers with the established guidelines for the mounting of BTSs and Masts in Abia State, Nigeria found significant difference between the mean value of the number of BTSs/Masts surveyed and the mean value of the number that complied with regulatory standards. The study further revealed that there were no significant differences between the telecommunication networks in their application of the environmental standards. The researchers therefore recommend that both NCC and 
NESREA be made to devolve their supervisory and monitory responsibilities to Town Planning Authorities at the local government level to ensure effective enforcement of the regulatory standards.

Ariyoosu [20] examined the legal regulation of telecommunications installations, especially masts and towers. It also considered the environmental impacts of telecommunication installations. It also considered the roles of concerned regulatory authorities vis-a-vis their regulatory functions in the provisions of effective telecommunications services through telecommunications installations and provision of healthy environment. Ariyoosu [20] found that despite the statutory regulation of telecommunications on one hand and the environment on the other hand, there appears to be statutory overlaps in the functions of regulatory authorities. This has resulted in a face-off among the relevant authorities. The issue is whether the provision of telecommunications services must be given priority to the detriment of a healthy environment. The paper recommended that there should be periodic review of relevant regulations and guidelines on telecommunications installations for effective service delivery without unnecessarily tampering with the health of the citizenry.

\section{Description of Study Area}

Jalingo, the capital of Taraba State lies roughly between latitude $8^{0} 47^{\prime}$ to $9^{0} 01^{\prime} \mathrm{N}$ of the equator and longitude $11^{0} 09^{\prime}$ to $11^{0} 30$ 'E of the Greenwich Meridian [21]. It is bounded to the north by Lau LGA, to the east by Yorro LGA, to the South and west by Ardo-Kola LGA. Jalingo has a total land area of about $195.071 \mathrm{~km}^{2}$. It has ten (10) wards comprising of Barade, Kachalla Sembe, Kona, Maji Dadi, Sarkin Dawaki, Sintali A, Sintali B, Turaki A, and Turaki B wards [21]. Presently, Jalingo Local Government Area has a projected population [22] of 176,068 people at $2.83 \%$ annual growth rate.

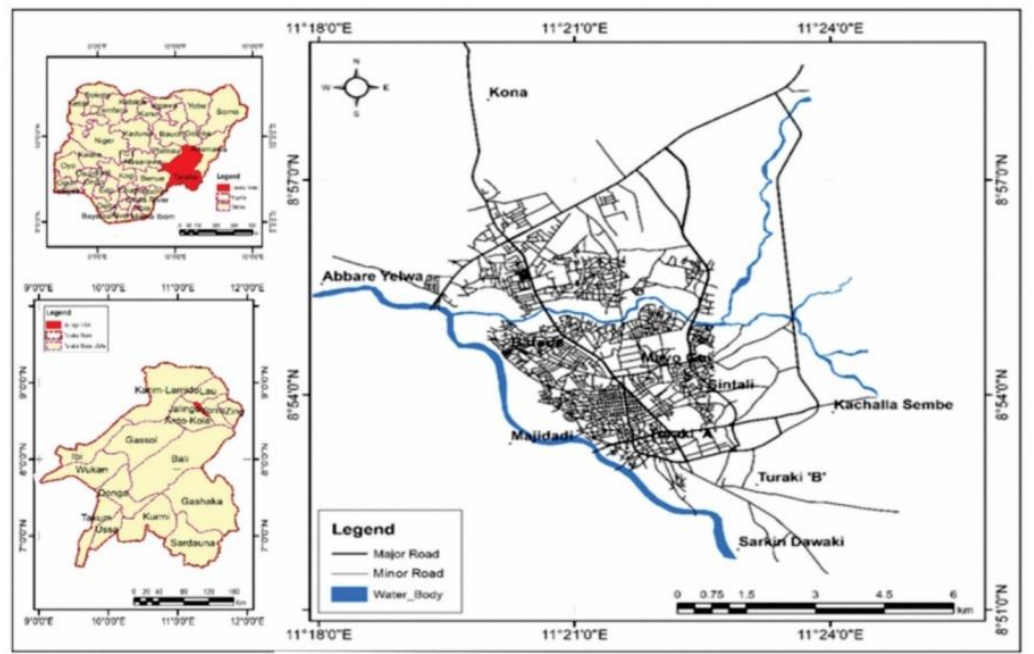

Fig-1: Map of the Study Area

\section{MATERIALS AND METHODS}

The study adopted survey research design which involves the use of direct observation and measurements. Primary data was sourced from field observation (ground truthing). This includes identification of the locations and collection of coordinates of GSM Base Transceiver Stations using Global Position System (GPS). Secondary data used included Digital Globe satellite image of the area obtained from Google Earth image online. The image was used to identify and extract the relevant features. Secondary data were also obtained from journals, government policy documents, online articles and newspaper publications.

The instruments or tools refer to the means through which the data was collected. Data for the study was collected with the help of Global Positioning System (GPS), measuring tape, and digital globe satellite image. Types of data used include:

i. Digital Globe Satellite image. ii. Coordinates of the GSM base stations' locations. The geographic positioning system (GPS) was used to collect the coordinates.

iii. Data on the GSM base stations record from various service providers and Nigeria Communication Commission (NCC). The data include the following:

a) Name of the various GSM Base Station.

b) The address and location of the base station.

c) Number of the base stations in the study area.

\section{Population of the Study}

The population of the study comprised all GSM base stations of mobile telecommunications companies operational in Jalingo town. Based on reconnaissance survey, 59 BTS stations were identified in Jalingo town.

\section{DATA ANALYSIS}

Data Processing: This involved the processing, extraction and analysis of relevant spatial and attribute 
information about the study area from the satellite image. The following steps were employed:

Image Geo-Referencing: The Digital Globe satellite image of the area was geo-referenced with the aid of ground control points using GPS. The image was geo-registered with the geographic coordinate system WGS 1984 using the Geo-referencing tool bar of the ArcGIS 10.1 software. The image was later projected to projection coordinate system Minna Datum zone 32 using the projection/transformation tool in the ArcToolBox of the ArcGIS software.

Vector Data Creation: The satellite image was vectorized using the ArcGIS 10.1 software. The purpose is to transform the raster image into vector shapefiles, where the image was digitized under the following themes: the road networks and water bodies as polylines. Residential areas as polygon with each feature type having separate attribute.

Geo-spatial Database: A geo-database was created using the ArcGIS 10.1 software, this enabled subsequent analysis, and querying and sorting was done. First the GSM base stations in Microsoft excel command delimited format with fields (column); $\mathrm{X}$ and $\mathrm{Y}$ locations, number of facilities, address, area, and corresponding records (row) was imported into the ArcGIS 10.1 software environment and exported into the Geo-database. Secondly digitized road networks, water bodies and residential areas from the satellite image was also exported into the Geo-database.

Data Analysis: The vector shapefiles in the database was imported into the ArcGIS environment to create a visual map of points and polygon feature classes. This shows the spatial location and distribution of base stations on the map across the study area.
NCC $5 \mathrm{~m}$ and NESERA $10 \mathrm{~m}$ Standard for locating GSM Base stations away from residential areas in Nigeria were adopted. The analyses were carried out as described below:

a. "Buffer Analysis": the buffering of 5 and 10 meters were created around GSM Base Stations using Buffer Tool of the Geoprocessing Tool Box in ArcGIS Environment to Analyze Proximity to Residential Areas.

b. "Proximity Analysis": The Database was queried to check the proximity of the Base station to the residential areas. The following queries were carried out"

i. Select by location residential areas within $5 \mathrm{~m}$ buffer of base station.

ii. Select by location residential areas within $10 \mathrm{~m}$ buffer of base station.

\section{RESULTS OF THE FINDINGS \\ Spatial Distribution of GSM Masts in Jalingo Town}

The map of Jalingo town was interpolated to show the spatial location of the masts as shown in Fig. 2. Masts in the study area are located within buildup areas, most of which are residential areas. Jalingo town is characterized by undulating landscape of rolling topography as observed by Oruonye [23]. Thus, most of the BTS are located within the relatively lowland area of Jalingo town.

Only one BTS was observed to be located in an isolated area with no buildup areas in Wuro Sembe, Kachalla Sembe ward. The BTS were also observed to be located more within the densely populated areas of the town as shown in Fig. 2.

\section{Location of gsm base station in jalingo}

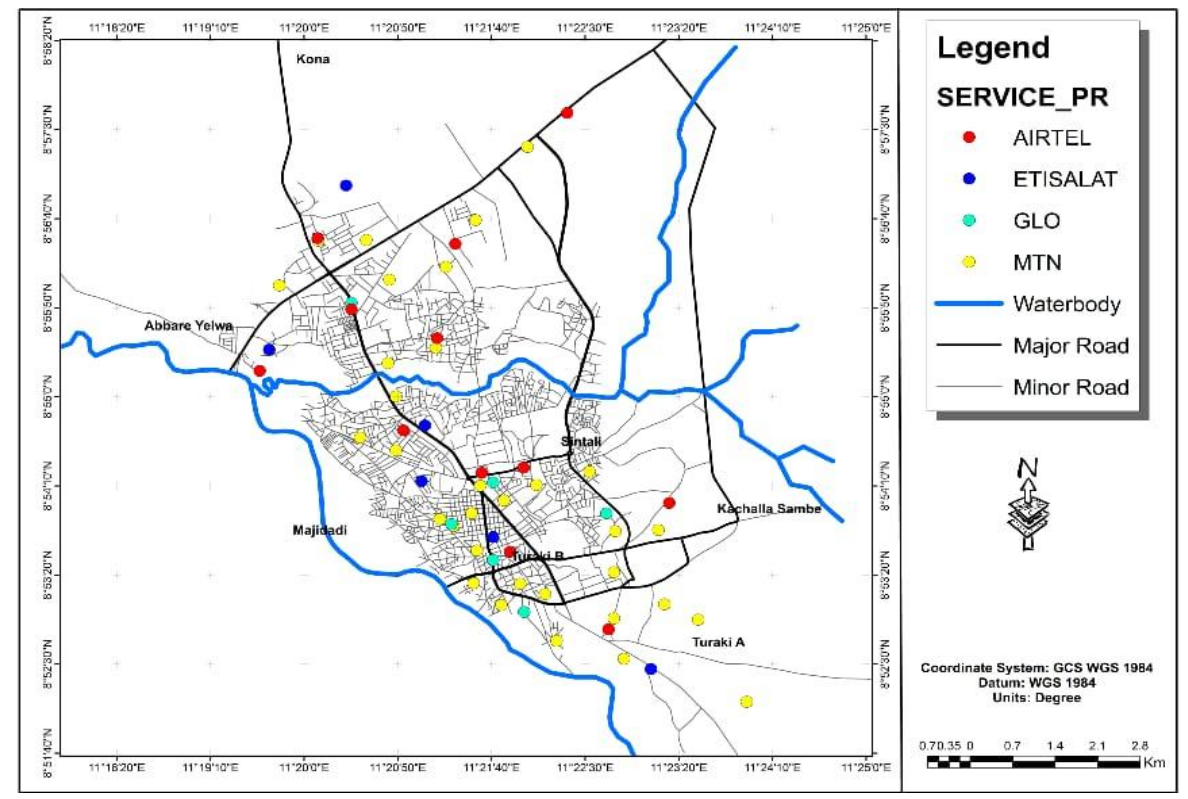

Fig-2: The Spatial Distribution of Masts 


\section{The Level of Compliance to Regulatory Standards}

A minimum regulatory setback distance of five meter $(5 \mathrm{~m})$ and ten meter $(10 \mathrm{~m})$ was used in the study as recommended by NCC and NESREA respectively [2]. The analysis was carried out to determine if the regulatory setback distance of mast to the nearest residents in the study area was complied with. Since the database created consists of distances from each mast to its nearest resident, the query tool analysis was used. The system was queried of those masts that are greater than or equal to 5 and 10 meters from the nearest resident property as shown in Figures 3 and 4 below.
Figures 3 and 4 show risk of selected GSM stations with red circular shape symbology representing NESREA 10 meter buffer from GSM based station and blue circular symbology representing NCC 5 meter restrictions from GSM based station. Figure 3 reveals that two buildings fall within the 5 meter NCC restriction and six building fall within NESREA 10 meter restriction while figure 4 reveals that two buildings fall within the 5 meter NCC restriction and five buildings fall within NESREA 10 meter restriction.

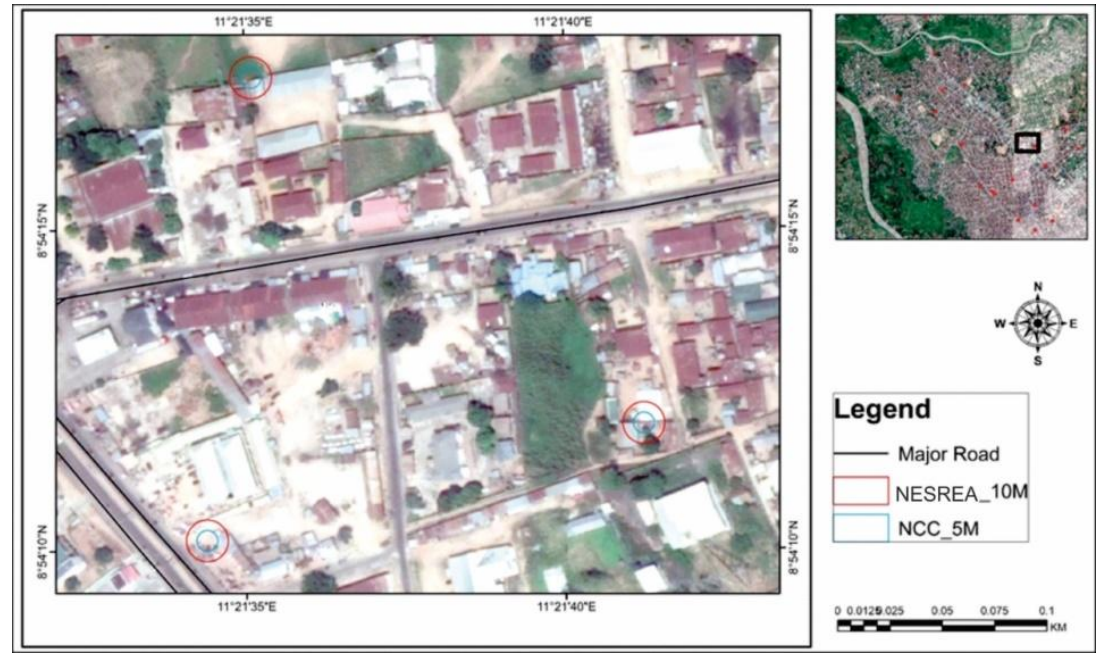

Fig-3: GSM Based Station Risk Map (Main Market Area, Jalingo)

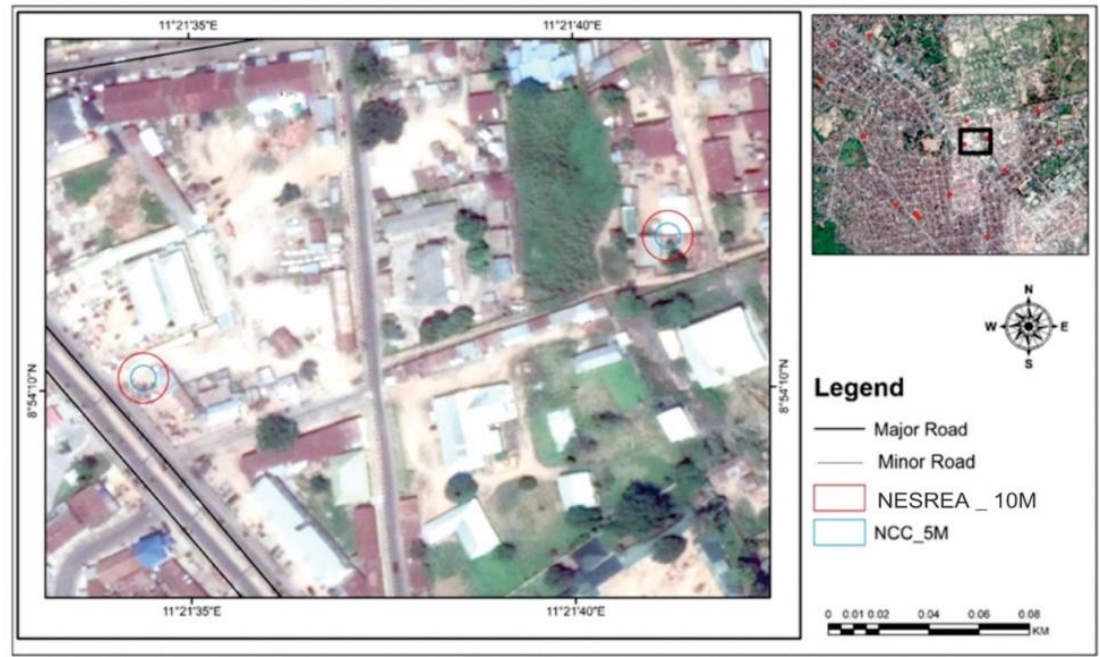

Fig-4: GSM Based Station Risk Map (Abuja Phase I Area, Jalingo)

Figure 5 shows the level of violation to regulatory standards by GSM operators in the installation of BTS across Jalingo town. The result shows that, of the 59 BTS studied in Jalingo town, only 6 representing $10.2 \%$ were installed according to regulatory standards. The remaining 53 representing $89.8 \%$ were erected not in line with the regulatory guideline of setback. The findings imply that there is high level of non-compliance in the installation of BTS in Jalingo town. The non-compliance could be attributed to the cost of acquiring large portion of land to cover the required setback. This results to people building houses around BTS. The lack of compliance can ultimately be blamed on the regulatory bodies for lack of adequate monitoring and enforcement of established laws and guidelines regulating the installation of BTS.

Lack of compliance to any rule or regulation comes with a price. The lack of compliance shown in Fig. 5 has its attendant consequences. This could result in 
cracks to buildings due to heavy vibrations from BTS generators. The spillage of diesel from the generators would infiltrate wells and affect quality (hardness) of water within these locations. During rainstorms, these telecom masts appear to be moving in the direction of wind. These masts installed around residential buildings can fall, causing human and environmental damage as is the case of a mast that fell, killed three persons and destroying properties around Taraba State Specialist Hospital, Jalingo [24, 23]. Also, telecom mast was reported, by Okunola [25], to have fell killing three persons in Port Harcourt. Similarly, Premium Times, in 2014, reported the case of a telecommunication mast erected in a residential area in Odukpani, near Calabar, which collapsed killing two persons, injuring three others and destroying several houses.

Aliyu [26] reported that the National Civil Aviation Authority (NCAA) had threatened to demolish over 7000 GSM Base station as a result of lack of compliance to statutory Aviation Height Clearance (AHC). These incessant cases of fallen masts and other environmental effects of BTS, which is ultimately connected to non-compliance to regulatory standards, calls for urgent action by all regulatory agencies saddled with such responsibility.

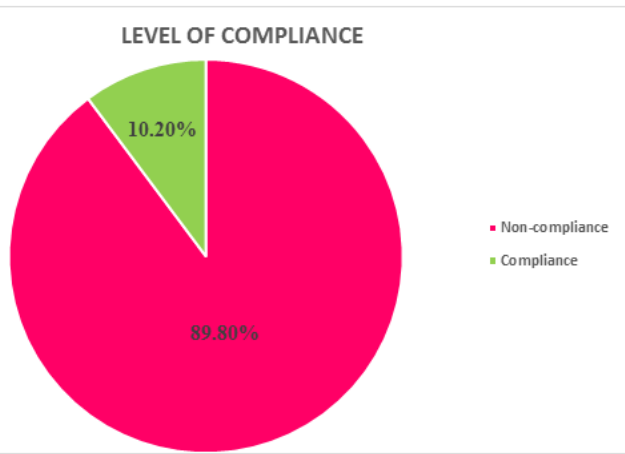

Fig-5: Level of compliance to regulation

\section{CONCLUSION}

This study has examined the level of compliance of GSM mast location to environmental standard regulations in Jalingo town, Nigeria. The study findings reveal that the indiscriminate installation of BTS/GSM masts in the study area has resulted in violation of environmental standard regulations. The study findings revealed that of the 59 GSM masts identified and investigated, only $10.2 \%$ GSM mast complied with the environmental regulatory standards, $89.8 \%$ did not comply with regulatory standards. The effects of this is deleterious to the environment in the long run.

\section{RECOMMENDATIONS}

Based on the findings of the study, the following recommendations are made:

i. There is need for the minimum regulatory setback distance policy to be harmonized by both the NCC and NESREA since noise hazards are still reported at some distance away. Also, laws and guidelines should be set for landowners on criteria for leasing out their land to telecommunication companies. This is to ensure adherence or non-violation of the regulatory setback distance.

ii. There is an urgent need for the regulatory agencies to intensify effort in enforcement of the statutory regulation guiding the installation of BTS by GSM operators to avoid further human and environmental damage.

\section{REFERENCES}

1. Godswill OC, Ugonma OV, Ijeoma EE. Telecommunication Masts/Base Transceiver Stations and Regulatory Standards in Abia State, Nigeria. Journal of Sustainable Development. 2016;9(6).

2. Nigeria Communication Commission (NCC); 2014. Industry information. Retrieved from http://www.ncc.gov.ng/index.php?option=com_con tent $\&$ view $=$ category $\& i d=65 \&$ Itemid $=67$

3. Aderoju OM, Ibrahim M, Onuoha HU, Adebowale RK, Oke AB. Assessment of the level of noise from base transceivers' station using geospatial techniques: In Abuja municipal area council. IOSR Journal of Environmental Science, Toxicology and Food Technology (IOSR-JESTFT) Volume. 2013 Nov; 7:30-9.

4. Bond S, Nick M, Karen B. Do Cellular Phone Base Station Towers affect Residential Property Values?. European Real Estate Society (ERES); 2003 Jun 1.

5. Kwan-Hoong N. Radiation, mobile phones, base stations and your health. Malaysian Communications and Multimedia Commission; 2003.

6. Bello MO. Effects of the Location of GSM Base Stations on Satisfaction of Occupiers and Rental Value of Proximate Residential Property. Computer and Information Science. 2010 Nov;3(4):159-70.

7. Olukolajo MA, Ezeokoli NB, Ogungbenro MT. Locational effect of GSM mast on neighbouring residential properties' rental values in Akure, Nigeria. Academic Journal of Interdisciplinary Studies. 2013 Nov 4;2(3):147-.

8. Cherry N. Health effects associated with mobile base stations in communities: the need for health studies. New Zealand: Lincoln University-Environmental Management and Design Division. 2000 Jun 8;8.

9. Lai H. Report on health effect of radiation from wireless transmitters. Department of Bioengineering, University of Washington; 2004. Retrieved August 15, 2018, from www.Salzburg.gv.at/henrylailetterspt132004.

10. Eneh OC. Environmental pollution health effects of electromagnetic radiations from antennae of telecommunication masts erected near residential and educational facilities in Enugu, Nigeria. Ciência e Técnica Vitivinícola Journal. 2015;30(9):146-54. 
11. Riggs R. The little-known dangers of EMFs and how to protect you and your family. Body Ecology. 2009.

12. Riggs R. Electromagnetic Hypersensitivity. IEEE Eng. Med. Biol. 2012; Sept/Oct: 173-175, Available at

http://ewh.ieee.org/soc/embs/comar/Hypersensitivit y.htm. Accessed 8/18/18.]

13. World Health Organization -WHO. Electromagnetic fields and public health: Mobile telephone and their base stations; 2007'.

14. AKIN AO, MARGARET A. Location Adequacy of Telecommunication Masts and Residents Livability in Osogbo, Nigeria. IMPACT: International Journal of Research in Applied, Natural and Social Sciences. 2014;2(11):7-16.

15. Bond S, Mun SY, Sakornvanasak P, McMahon N. The impact of cellular phone base station towers on property values. InUnpublished conference paper presented at the Ninth Pacific-Rim Real Estate Society Conference, Brisbane, Australia 2003 Jan 19 (Vol. 19, p. 22).

16. Tarantino A. Governance, risk, and compliance handbook: technology, finance, environmental, and international guidance and best practices. John Wiley \& Sons; 2008 Mar 11.

17. Silberman JD. Does Environmental Deterrence Work: Evidence and Experience Say Yes, but We Need to Understand How and Why. Envtl. L. Rep. News \& Analysis. 2000; 30:10523.

18. OECD. Sustainable Development: Critical Issues. OECD, Paris; 2001.
19. Nigeria Communication Commission (NCC). The Guidelines on Technical Specifications for the Installation of Telecommunications Masts and Towers; 2009 (NCC Guidelines 2009) s.9(9)(c). Abuja: NCC.

20. Ariyoosu DA. An Examination of legal regulation and environmental impacts of telecommunications installations in Nigeria. Journal of Law, Policy and Globalization. 2014;30:88-96.

21. Oruonye ED, Abbas B. The Geography of Taraba State, Nigeria. LAP Lambert Academic Publishing, Germany. 2011.

22. Oruonye ED. Geographical aspects of Jalingo region. Phimela Concept Printing Press, Jalingo. 2014.

23. Ojeh VN, Oruonye ED, Arisabor L, Jutum F, Dovo J, Mubwi I, Audu G, Daniel S, Bawa W, Joseph JM, Semaka S. The impact of the episodic rainstorm event of 18th April and 5th May, 2018 in Taraba State, Nigeria. International Journal of Environment and Climate Change. 2019;9(3):150-9.

24. Papa, A. 7 Dead as communication mast falls after heavy storm in Jalingo.2018. http://www.naijaloaded.com.ng retrieved on August $10,2018$.

25. Okunola F. Mast Collapses, Kills 3 in Port Harcourt. 2017; Retrieved 21 October 2018 from https://www.pulse.ng/news/tech/mast-collapses-kill s-3-in-port-harcourt.html

26. Aliyu A. NCAA to demolish 7,000 telecom masts, issues 30-day ultimatum; 2019 https://www.dailytrust.com.ng/ncaa-to-demolish-70 00-telecom-masts-issues-30-day-ultimatum.html. 